\title{
Daya tindak perlokusi pengguna instagram dalam unggahan bertema Covid-19
}

\author{
A. A. Ayu Dian Andriyani ${ }^{2, I^{*}}$, I Dewa Ayu Devi Maharani Santika ${ }^{a, 2}$, Yusuf Muflikh Raharjo ${ }^{b, 3}$ \\ ${ }^{a}$ Fakultas Bahasa Asing Universitas Mahasaraswati Denpasar, Jl. Kamboja No.I IA, Dangin Puri Kangin Kota Denpasar, Bali, \\ Indonesia \\ ${ }^{\mathrm{b}}$ Universitas Sebelas Maret, J1. Ir. Sutami No.36, Kentingan Kota Surakarta, Indonesia \\ Iagungdianunmas@gmail.com, devimaharani17@gmail.com²,yusufmr.uns@gmail.com³ \\ *Corresponding author: agungdianunmas@gmail.com
}

\begin{tabular}{|c|c|c|}
\hline & ri 202I & \\
\hline \multicolumn{3}{|c|}{ ABSTRAK } \\
\hline \multicolumn{3}{|c|}{$\begin{array}{l}\text { Tindak perlokusi merupakan respons dari mitra tutur akibat adanya suatu tindakan. Artinya hasil tinda } \\
\text { adanya daya pengaruh terhadap mitra tutur. Penelitian ini bertujuan menemukan makna tindak perlo } \\
\text { unggahan bertema Covid-19 milik akun Kemenkes_ri. Sumber data penelitian bukan berasal dari dia } \\
\text { bersifat semuka, melainkan pertemuan maya melalui teknologi digital di media sosial yaitu, instagram. } \\
\text { adalah respons para followers terhadap hasil unggahan dari Kemenkes-ri. Penelitian ini menggunakan m } \\
\text { dengan teknik pengumpulan data yaitu, mendokumentasi, membaca, dan mencatat setiap komentar } \\
\text { @kemenkes_ri bertemakan Covid I9 selama } 6 \text { bulan. Pendekatan padan pragmatik untuk n } \\
\text { diklasifikasikan guna mengelompokkan data berupa teks yang mengandung daya perlokusi. Metode } \\
\text { padan pragmatik didukung oleh konteks situasi. Hasil penelitian menemukan dua jenis respons baik p } \\
\text { makna tindak perlokusi sangat bervariasi. Respons positif bentuk (I) apresiasi, (2) dukungan serta (3 } \\
\text { dan kegiatan pemerintah, sedangkan respons negatif mengandung (I) kekecewaan, (2) kemarahan, (3) } \\
\text { kurang percaya terhadap kebijakan pemerintah dalam menangani Covid-19 di Indonesia. Berbagai res } \\
\text { rakyat kepada pemerintah untuk lebih sigap dalam menangani kasus Covid-19 di Indonesia. }\end{array}$} \\
\hline \multirow{2}{*}{\multicolumn{3}{|c|}{ Covid-I9, Daya tindak perlokusi, Instagram }} \\
\hline & & \\
\hline \multicolumn{3}{|c|}{$\begin{array}{l}\text { Perlocutionary action is the response of an action. One's actions allow the power to influence speech partners. This study } \\
\text { aimed to find the meaning of followers' perlocutionary acts as the results of the posts with the theme of Covid-I9 from } \\
\text { the Indonesian Ministry of Health Instagram account, which was the source of this study. The primary data were the } \\
\text { followers' responses to the posts of the account. The method was the uninvolved direct conversation method engaging } \\
\text { with data collection techniques; documentation techniques, reading techniques and note-taking of the comments uploaded } \\
\text { on the account for } 6 \text { months. The pragmatic equivalent approach was used to analyze the data in the form of text } \\
\text { containing perlocutionary power and was supported by the context of the situation. The results found two types of } \\
\text { responses, positive and negative, with various meanings of perlocutionary actions. Positive responses show (I) } \\
\text { appreciation, (2) support and (3) hope for government policies and activities, while negative responses contain (I) } \\
\text { disappointment, (2) anger, (3) resentment, (4) questions of lack of confidence in government policies in dealing with } \\
\text { Covid-I9 in Indonesia. These represent the people's aspirations to the government to be alert in handling the Covid-I9 } \\
\text { case in Indonesia. }\end{array}$} \\
\hline & & \\
\hline How to Cite & & \\
\hline
\end{tabular}

\section{PENDAHULUAN}

Tindak tutur adalah interaksi bertutur oleh penutur kepada mitra tutur (Yule, 1996). Penggunaan tindak tutur dalam interaksi merupakan suatu kajian dalam konteks dan situasi bahasa yang disebut dengan kajian tindak tutur (Parker, 1986). Setiap tuturan penutur dimungkinkan mengandung bentuk dengan maksud yang beranekaragam tergantung dari konteks situasi yang mengikuti. Tindak 
tutur sangat terikat dengan konteks situasi pada setiap peristiwa tutur (Fatma, 2016; Safar, 2016; Safrihady \& Mardikantoro, 2017; Susanti et al., 2010). Sebuah tuturan mengandung tiga komponen pokok, yakni, tindak lokusi (locutionary act), tindak ilokusi (illocutionary act), tindak perlokusi (perlocutionary act) (Jumanto, Nugroho, \& Basari, 2018; Leech, 1996; Parker, 1986; Pramujiono, Suhari, Indrayanti, \& Rochmawati, 2019; Searle, 1985; Yule, 1996). Tindak tutur yang paling sederhana untuk mengungkapkan sebuah bahasa dengan makna leksikal dari kata sebenarnya, mendeskripsikan apa yang dikatakan pembicara merupakan tindak lokusional. Berbeda dengan tindak tutur ilokusional menyatakan maksud pembicara untuk melakukan sesuatu, sangat bergantung pada maksud, niat, dan tujuan penuturnya (Kempson, 1977; Searle, I985). Sedangkan tindak tutur perlokusi dapat disebut juga sebagai tindak mempengaruhi orang lain karena berefek dan memiliki daya pengaruh (perlocutionary force) bagi mitra tutur (Kumalasari, Rustono, \& Santoso, 2018; Lee, Lee, \& Chun, 2018; Parker, I986; Rahayu, 2020; Searle, I985; Shaari, 2020). Artinya adalah tindak perlokusi lebih terfokus pada bagaimana respons atau efek yang dimunculkan dari mitra tutur (Austin, 1962).

Penelitian mengambil objek di media sosial instagram dengan topik Covid-19, yang secara umum merupakan penelitian tergolong baru karena pandemi merupakan suatu fenomena yang baru saja terjadi secara mendunia termasuk Indonesia. Karena tergolong suatu kondisi baru, sehingga para peneliti belum banyak mengambil topik bertemakan Covid-I9 di media sosial instagram terutama dalam kajian tindak perlokusi, yang merupakan hasil unggahan pemilik akun tertentu. Meskipun ilmu linguistik semakin berkembang namun topik yang dikaji bukan tentang dampak hasil unggahan yang bertemakan Covid-19, melainkan objek kajian tindak tutur di media sosial dengan topik yang sangat bervariasi. Apalagi saat ini, pada masa era digital, penelitian juga mengalami perkembangan, banyak peneliti menghasilkan kolaborasi dengan mengambil objek penelitian di media sosial. Salah satu media sosial yang memiliki pengguna yang sangat tinggi adalah instagram. Hal ini disebabkan oleh kemudahan pengguna dalam membagikan unggahan berupa foto, video yang mengandung informasi maupun memperkenalkan produk baik jasa maupun barang di instagram (Hamidah, 2015).

Penelitian-penelitian tersebut telah menghasilkan temuan diantaranya, makna tindak tutur ilokusi dalam upacara ngidih di Kota Denpasar (Netra, 2013); fungsi pragmatik pada kolom Smart Traveler surat kabar Tribun Bali (Citrawati, Teguh, \& Widarsini, 2020); implementasi tindak tutur dalam ranah tourism wisatawan di Bali (Andriyani, 2020). Selain tindak tutur lokusi maupun ilokusi banyak temuan dari penelitian yang mengambil objek penelitian daya tindak tutur perlokusi yaitu (Mujianto, 2015; Mukhroji, Nurkamto, Subroto, \& Tarjana, 2019; Pande \& Artana, 2020; Rahardi, 2020) hasil temuan menunjukkan bahwa dalam tindak tutur perlokusi baik dalam ranah yang beranekaragam akan menumbuhkan daya pengaruh tindak perlokusi yang beraneka ragam. Dewasa ini, mengingat masih merebaknya virus Covid-19, masyarakat diharuskan untuk berinteraksi secara daring sehingga media sosial sebagai sumber yang tepat. Media sosial dianggap mampu memberikan berbagai informasi. Telah dilakukan berbagai penelitian tindak tutur menggunakan media sosial instagram sebagai sumber data penelitian yang menghasilkan berbagai temuan (Andriyani \& Rahayu, 2019; Hamidah, 2015; Khalisah \& Anjarningsih, 2020; Nuramila, 2017; Suryani, 2014).

Banyaknya informasi yang diterima memunculkan komentar yang beraneka ragam baik secara positif maupun negatif terhadap berbagai unggahan. Bentuk respons dari pembaca merupakan bentuk apresiasi dari daya pengaruh yang dimunculkan akibat adanya unggahan sebagai implementasi dari tindak tutur perlokusi yang sangat menarik untuk dikaji lebih dalam. Berdasarkan fenomena yang terjadi saat ini dengan berbagai hasil temuan tindak tutur, umumnya hasil penelitian mengkaji tindak tutur lokusi maupun ilokusi saja, sehingga tindak tutur yang mengandung daya pengaruh terhadap mitra tutur salah satunya pembaca sangat menarik untuk dikaji. Selian itu, dengan memahami daya pengaruh yang muncul maka pengguna media sosial menjadi lebih bijak dalam mengunggah berbagai informasi terkini melalui media sosial yaitu, instagram. Penelitian ini membuktikan bahwa sebuah unggahan berupa berita atau informasi yang ada pada instagram ternyata memancing para warganet untuk berkontribusi dalam bentuk komentar. Komentar-komentar yang muncul bisa saja hanya sekadar meramaikan atau sampai 
pada tataran memberikan kontribusi yang memiliki pengaruh perlokutif dan berdampak pada pengunggah maupun warganet yang lain. Penelitian ini bertujuan untuk menemukan makna tindak perlokusi followers terhadap hasil unggahan bertema Covid-19 milik akun Kemenkes. Kontribusi penelitian ini pada umumnya ditujukan kepada masyarakat dalam ranah penyebaran informasi Covid-I9 yang sangat dibutuhan khususnya warganet. Berbagai respons terlihat mewakili aspirasi rakyat kepada pemerintah untuk lebih sigap dalam menangani kasus Covid-19 di Indonesia.

\section{METODE}

Penelitian ini merupakan penelitian kualitatif, yang bertujuan untuk mendeskripsikan makna dari daya tindak perlokusi akun instagram milik Kemenkes_ri hasil unggahan bertema covid-19. Sumber data substantif penelitian ini bukan interaksi yang terjadi secara alami dalam satu konteks tertentu antara penutur dengan mitra tutur, tidak berasal dari dialog natural diantara peserta tutur dengan menggunakan bahasa keseharian yang bersifat semuka, melainkan sebuah pertemuan maya antara pemilik akun dengan para followers melalui teknologi digital di media sosial yaitu, instagram berupa teks-teks tertulis dari para followers pada setiap hasil unggahan. Sumber data dalam penelitian ini adalah media sosial instagram dengan pemilik akun@kemenkes_ri. Data primer berupa komentar tertulis dari pembaca selaku followers, setelah membaca hasil unggahan akun instagram milik@kemenkes_ri sebagai media informasi kesehatan bagi masyarakat terutama dalam penanganan Covid-19.

Penelitian ini menggunakan metode simak bebas, libat, cakap (Sudaryanto, 2015) dengan teknik mendokumentasi, membaca, dan mencatat setiap komentar hasil unggahan akun@kemenkes_ri bertemakan Covid-19 selama 6 bulan sejak bulan Juli 2020 sampai Desember 2020. Data yang telah diperoleh kemudian diseleksi, diklasifikasi sesuai dengan rumusan masalah, serta divalidasi dengan menggunakan triangulasi data, kemudian dianalisis.

Metode padan pragmatik merupakan metode yang ditentukan oleh pihak mitra tutur. Hal ini dikarenakan dengan menggunakan metode padan dapat menentukan dengan baik respons mitra tutur karena alat penentu adalah mitra tutur itu sendiri. Metode ini digunakan untuk menganalisis data yang telah diklasifikasikan secara detail, yang bermanfaat untuk mempermudah dalam mengelompokkan data berupa teks yang mengandung daya perlokusi hasil unggahan pemilik akun@kemenkes_ri bertemakan Covid-19. Metode ini tepat digunakan karena sesuai dengan data-data unggahan telah memunculkan daya pengaruh terhadap mitra tutur. Sebelum menganalisis dan memvalidasi data, terlebih dahulu melakukan triangulasi data, kepada pakar yang berkompeten di bidangnya sebagai pendukung penelitian serta menggunakan teori-teori yang relevan. Metode analisis data yang digunakan adalah metode padan pragmatik didukung oleh konteks situasi. Hasil analisis dideskripsikan secara informal menggunakan kata-kata biasa bersifat natural.

\section{HASIL DAN PEMBAHASAN}

Penelitian ini menemukan suatu fenomena kebahasaan berupa adanya daya pengaruh tindak perlokusi ditandai dengan banyak munculnya respons atau komentar-komentar, baik yang bersifat positif maupun negatif mengandung makna bervariasi tergantung konteks situasi yang mengikuti. Setelah data diperoleh mengikuti teknik pengumpulan data yang tepat, maka dilanjutkan dengan memvalidasi data yang telah diperoleh. Kemudian mengonfirmasi kepada para pakar dan membaca teori-teori yang relevan dengan penelitian. Berikut adalah hasil dari tindak perlokusi dan respons dari data yang telah diperoleh sebagaimana Tabel I.

Tabel I

Tindak Perlokusi dan Respons

\begin{tabular}{cccccc}
\hline $\begin{array}{c}\text { Data } \\
\text { Teks }\end{array}$ & Bentuk Tuturan & $\begin{array}{c}\text { Jumlah } \\
\text { Komenta } \\
\mathbf{r}\end{array}$ & $\begin{array}{c}\text { Respons Positif } \\
\text { Wujud Tindak } \\
\text { Perlokusi }\end{array}$ & $\begin{array}{c}\text { Respons Negatif Wujud Tindak } \\
\text { Perlokusi }\end{array}$ \\
\hline Data (I) & Sudah siap untuk melakukan & II4 & Mengapresiasi & Memposting gambar muka tertawa
\end{tabular}




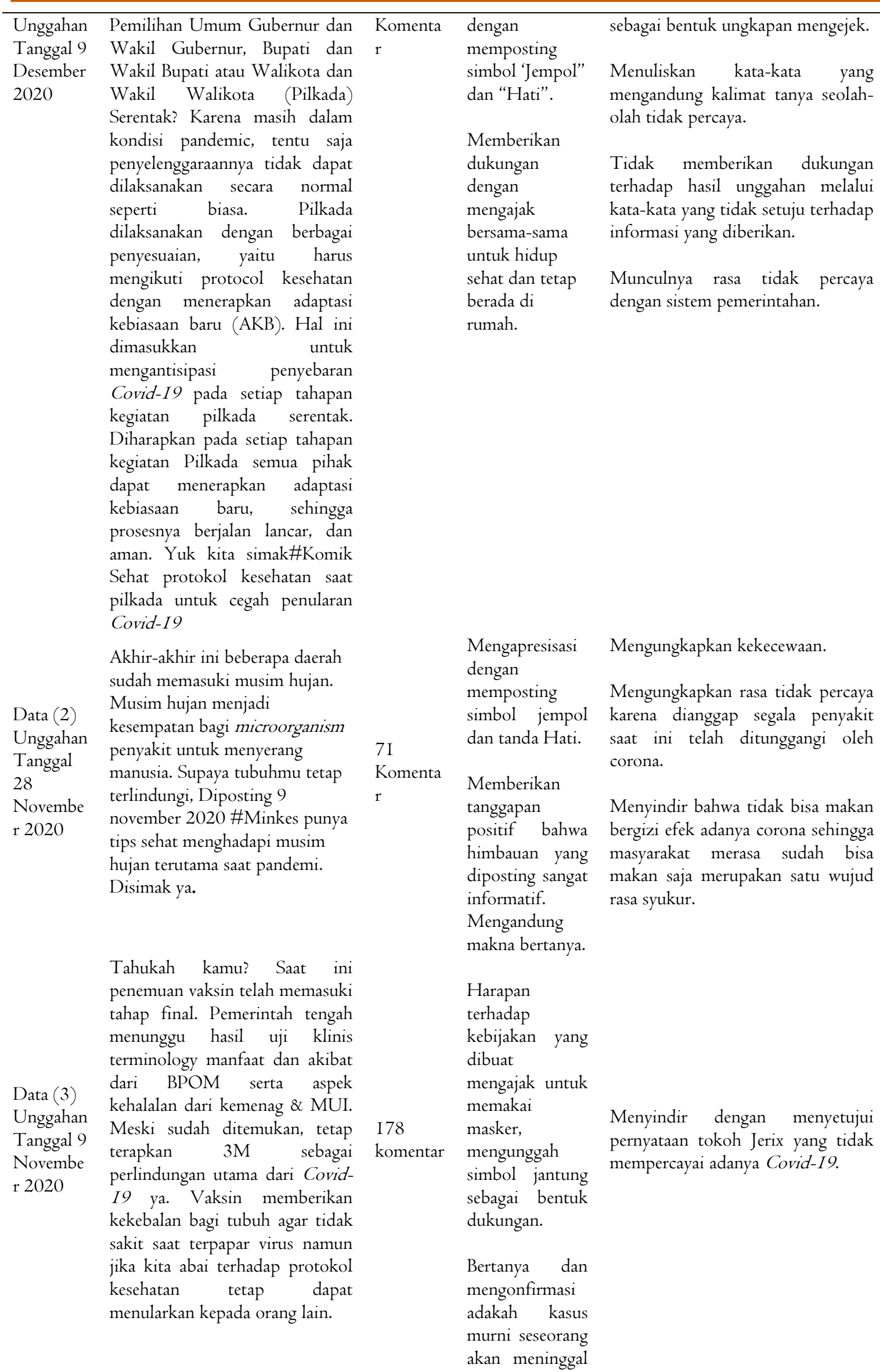


karena Covid-

I9.

Bagi \#Healthies yang ingin berbelanja di pasar tradisional sudah tahu belum apa saja yang menjadi protokol kesehatan saat kita berada di pasar tradisional? Saat masa adaptasi kebiasaan baru ini kita harus tetap disiplin menjalankan protokol kesehatan ya jangan abai dengan kesehatan, yuk! Simak komik sehat berikut.

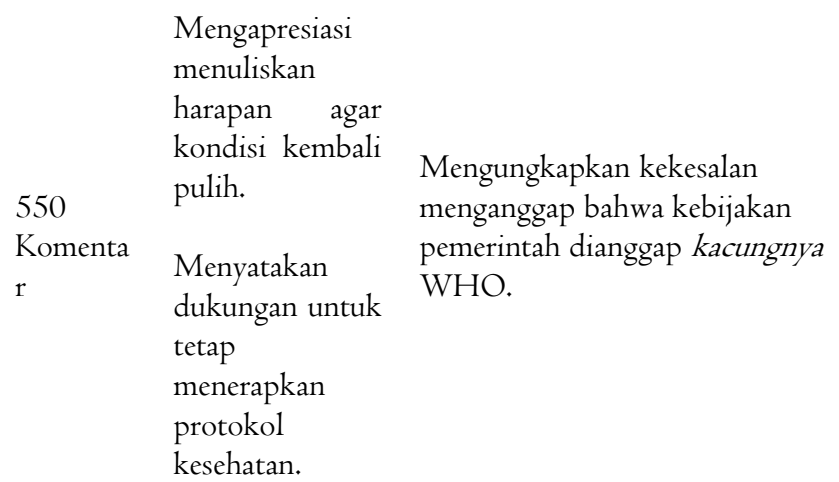

Mengapresiasi

Data (4)

Unggahan

Tanggal

I4 Juli

2020

kesehatan.

Berdasarkan data yang telah didapat dan diklasifikasikan, dilakukan triangulasi dengan baik kepada pakar terkait dan penggunaan teori-teori yang relevan. Kemudian data dianalisis dengan menerapkan metode dan teknik tertentu untuk menghasilkan temuan, temuan berupa komentar atau respons pembaca atas unggahan bertemakan Covid-19 yang sedang terjadi saat ini.

Dampak tindak tutur perlokusi merupakan hasil dari unggahan pemilik akun@kemenkes_ri ke media sosial yaitu instagram. Banyak hasil penelitian sebelumnya telah meneliti daya tindak perlokusi dengan objek penelitian tuturan lisan maupun tertulis. Secara lisan telah diteliti tentang konferensi pers oleh Presiden yang dikaji tindak tutur perlokusinya (Fatihah \& Utomo, 2020). Penelitian ini telah membuktikan bahwa Tindak tutur perlokusi juga dapat ditemukan melalui media online seperti video YouTube. Hal ini dapat dilihat dari daya pengaruh dan efek dari penutur kepada mitra tutur secara langsung maupun tidak langsung melalui adanya penanda tuturan yang mengandung makna melaporkan, menakut-nakuti, permintaan, perintah, melegakan, menyenangkan sehingga memunculkan adanya efek tidak panik, efek takut, efek melakukan permintaan, efek melakukan kebijakan, efek melaksanakan perintah, efek senang, efek menerima ajakan, efek menuruti permintaan. Berbeda dengan hasil penelitian Meylinda (2019) yang menyatakan adanya daya pengaruh dari host Aiman ketika bertutur lisan kepada narasumber untuk melakukan suatu tindakan dengan penggunaan verba meyakinkan, membuat jengkel, mengintimidasi, menganjurkan, dan menuduh. Namun hasil penelitian dengan objek penelitian berupa tulisan atau teks juga telah menemukan tindak tutur perlokusi dalam karikatur milik koran Kompas. Hasil penelitian menemukan adanya daya pengaruh dari tindak perlokusi mengacu pada lima jenis tindak tutur.

Temuan yang sama dalam teks juga mengaji komponen tindak tutur yang terdiri atas tindak tutur lokusi, ilokusi, dan perlokusi pada salah satu wacana yang terdapat di koran Tribun Pontianak yang mendeskripsikan bahwa koran sebagai sumber informasi, bagian dari media massa (Hartati, 2016). Penelitian ini telah menemukan daya pengaruh tindak perlokusi tidak saja terlahir dari tuturan secara lisan saja, melainkan dari data secara tertulis misalnya pada rubrik suara rakyat khususnya di halaman hotline mengenai pembuatan akta lahir. Selain itu, daya tindak perlokusi juga dapat ditemukan dalam wacana iklan motor dan mobil dalam harian umum Solopos (Wulan, 2016). Berdasarkan hasil penelitian tersebut semakin jelas bahwa ketika tuturan maupun suatu teks dibaca oleh mitra tutur, tentunya akan menimbulkan daya pengaruh. Akan tetapi, berbeda ketika berbicara dengan benda mati yang tidak akan merespon karena benda tersebut tidak mampu bergerak bahkan berpikir. Saat ini banyak hasil penelitian memanfaatkan media digital dengan mengambil tema Covid-I9 sebagai bahan penelitian yang mampu menimbulkan banyak respons. Hasil penelitian yang menemukan daya perlokusi hoaks Covid-I9 mengandung (I) mengentalkan rasa sentimen; (2) menumbuhkan persepsi keliru; (3) menyindir otoritas; (4) menumbuhkan kegaduhan; (5) menebar ketakutan; (7) menumbuhkan kekhawatiran; dan (8) menumbuhkan kasak-kusuk (Rahardi, 2020). Unggahan ini dalam bentuk teks namun daya pengaruhnya sangat besar. Hal ini memberikan gambaran bahwa meskipun unggahan bukan 
berwujud suatu tuturan, namun unggahan dalam bentuk teks pun mampu memunculkan respons yang sama asalkan topik yang diunggah sedang tren, sehingga mampu memberikan daya pengaruh bagi pembaca sebagai bentuk apresiasi pembaca baik dalam bentuk respons positif maupun negatif.

$\operatorname{Data}(I)$

Konteks Situasi:

Komik gambar dan kalimat deskripsi merupakan unggahan dari pemilik akun @kemenkes_ri berisi tata cara yang tepat sebagai implementasi dari protokol kesehatan saat musim PILKADA guna mencegah penularan virus Covid-19
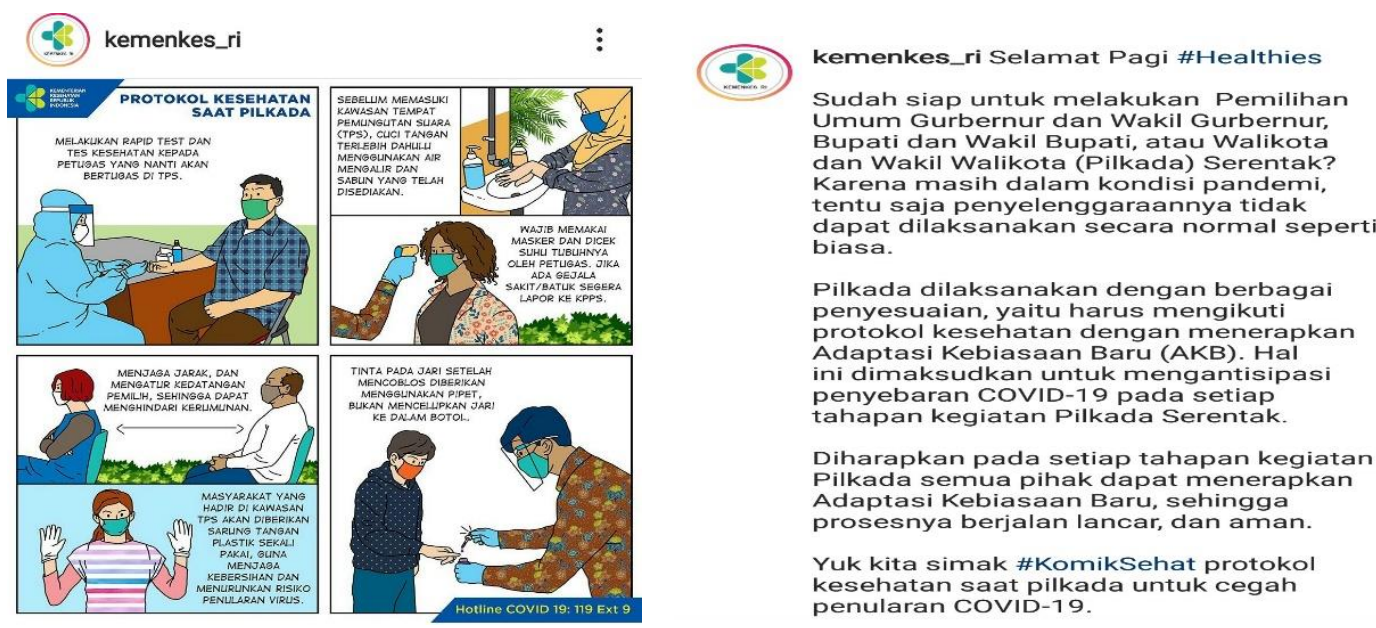

Gambar I.Unggahan @kemenkes_ri tentang protokol kesehatan saat Pilkada

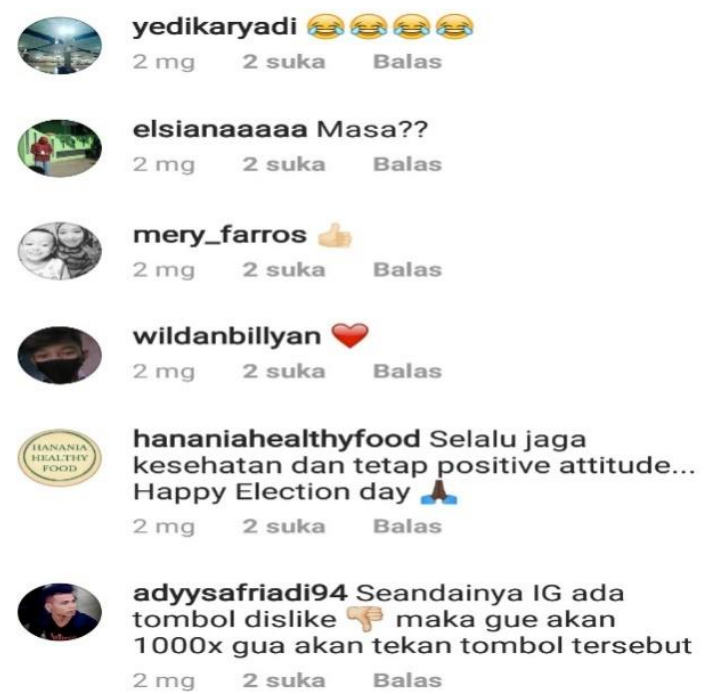

Gambar 2. Komentar pada unggahan @kemenkes_ri tentang protokol kesehatan saat Pilkada

\section{Analisis Data (I)}

Unggahan pada data (I) ditampilkan komik gambar dilengkapi dengan keterangan di bawahnya, unggahan tersebut mengandung informasi dan mengonfirmasi kepada pembaca. Informasi yang diberikan adalah tata cara protokol kesehatan saat mengikuti pilkada. Pada unggahan ini juga menggunakan kalimat ajakan pada pembaca untuk menyimak dialog pada komik gambar yang telah diunggah. Unggahan dari pengguna instagram milik@kemenkes-ri mengimbau untuk tetap mematuhi 
protokol kesehatan pada pilkada 2020 dengan tujuan tidak terjadi penularan Covid-I9. Artinya, konteks situasi tutur di atas, memberikan gambaran bahwa pemerintah mengajak masyarakat untuk tetap waspada dan disiplin mengikuti protokol kesehatan meskipun saat akan memilih.

Daya pengaruh dari unggahan merupakan wujud tindak tutur perlokusi (Tsoumou, 2020). Fenomena ini menunjukkan bahwa dampak tindak perlokusi berita dapat ditemukan apabila aspekaspek dalam konteks eksternal konvensional diperinci dengan baik, sehingga akan menghasilkan efek atau hasil berupa ungkapan itu pada pendengar, sesuai dengan situasi dan kondisi pengucapan kalimat (Rahardi, 2020). Tindak perlokusi telah memunculkan daya pengaruh berupa berbagai respons dari masyarakat selaku pengguna instagram. Adapun tanggapannya sangat bervariasi, baik yang pro maupun kontra terhadap hasil unggahan. Hal ini dapat dilihat dari respons pemilik akun@nabil.ayasmin menuliskan adanya kekecewaan yang selama ini telah dirasakan akibat dampak pandemi. Rasa kecewa terhadap kebijakan proses belajar mengajar di sekolah yang mengharuskan dilakukan secara daring. Namun, berbanding terbalik dengan fenomena yang terjadi ketika adanya pilkada, masyarakat diminta untuk keluar rumah, meskipun mengikuti protokol kesehatan. Respons positif dengan memberikan simbol hati sebagai bentuk apresiasi terhadap unggahan yang mengandung himbauan bermanfaat bagi masyarakat apalagi di masa pandemi seperti sekarang ini. Berbeda dengan respons positif dari akun milik @mery_farros, yang memberikan respons dengan bentuk lambang jempol, dan pemilik akun @ wildanbillyan yang memberikan respons dengan bentuk lambang jantung sebagai dukungan terhadap unggahan dari@kemenkes-ri. Selain itu, tanggapan positif juga diberikan oleh pemilik akun @ hananiahealthyfood yang memberikan komentar bersifat mengajak pembaca agar menjaga kesehatan dan selalu bersikap positif. Banyaknya respons dari pengguna instagram memberikan suatu pemahaman bahwa unggahan telah memunculkan tindak perlokusi dalam bentuk positif maupun negatif. Fenomena ini telah membuktikan bahwa tindak perlokusi telah memberikan suatu daya pengaruh yang besar bagi mitra tutur. Artinya mitra tutur mampu merespons baik tuturan secara lisan maupun dalam bentuk tertulis melalui unggahan melalui media sosial yaitu instagram (Parker, 1986; Searle, I983).

Data (2):

\section{Konteks Situasi:}

Konteks situasi pada data (2) adalah unggahan@kemenkes_ti dalam bentuk komik gambar berisi dialog ketika musim hujan dan kalimat deskripsi mengandung himbauan kepada masyarakat. Isi unggahan mengandung bagaimana kiat-kiat untuk menghadapi musim hujan saat pandemi.

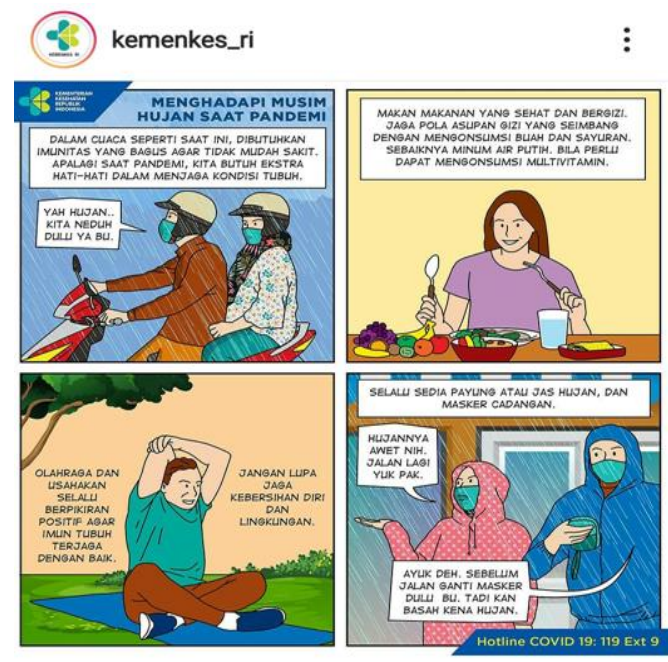

kemenkes_ri \#Healthies! Akhir-akhir ini beberapa daerah sudah memasuki musim hujan. Musim hujan menjadi kesempatan bagi microorganisme penyakit untuk menyerang manusia

Supaya tubuhmu tetap terlindungi, \#Minkes punya tips sehat menghadapi musim hujan terutama saat pandemi. Disimak ya ()

Gambar 3. Unggahan @kemenkes_ri tentang menghadapi musim hujan saat pandemi 


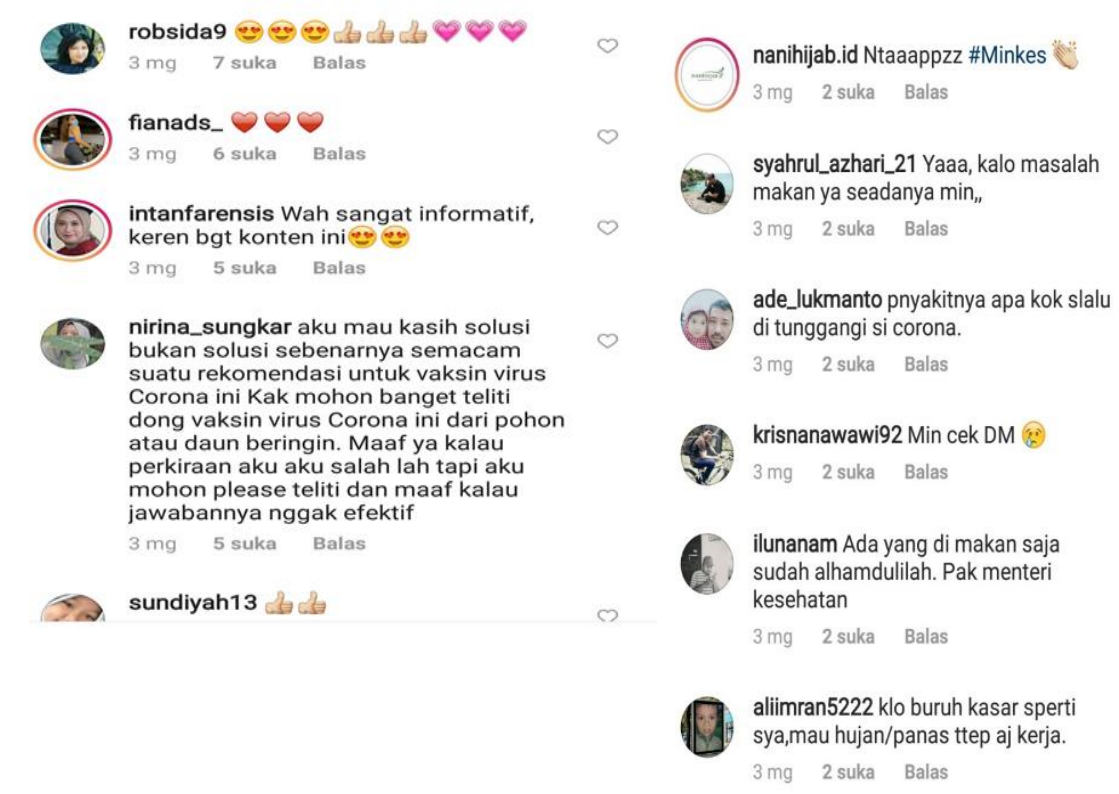

Gambar 4. Komentar pada unggahan @kemenkes_ri tentang menghadapi musim hujan saat pandemi

\section{Analisis Data (2)}

Hasil unggahan pada data (2) mengandung topik yang sangat bermanfaat bagi para follower instagram. Isi dari unggahan adalah mengingatkan kepada masyarakat untuk tetap menjaga kesehatan karena saat ini memasuki musim penghujan. Agar unggahan menarik dan menjadi pusat perhatian, maka selain berupa teks, juga didukung oleh adanya gambar-gambar sehingga mudah untuk dipahami. Pemilik akun instagram@kemenkes-ri telah mengunggah informasi dalam bentuk teks dan komik gambar pada tanggal 9 November 2020. Hasil unggahan tersebut menciptakan daya pengaruh terhadap follower atau pengguna akun lain media sosial instagram. Artinya, isi unggahan telah memberikan pengaruh positif maupun negatif kepada pengguna instagram yang membaca, hal ini dapat dilihat dari berbagai respons yang muncul (Bou-Franch \& Garcés-Conejos Blitvich, 20I4). Tindak perlokusi menumbuhkan persepsi keliru itu adalah dampak, pengaruh, bukan maksud itu sendiri (Rahardi, 2020). Ketika unggahan dianggap memberikan manfaat positif, maka respons pembaca menuliskan berbagai jenis komentar yang mendukung, dan mengapresiasi dengan memberikan simbol jempol serta simbol hati. Selain itu, respons positif lainnya menuliskan kata-kata "mantap \#Minkes", "wah sangat informatif, keren banget", konten ini didukung oleh simbol muka dengan mata berisi hati sebagai ungkapan rasa berterima kasih atas informasi yang diberikan kepada pengguna instagram.

Namun di sisi lain, mengandung respons negatif. Dari 7I komentar yang diunggah rata-rata mengandung sindiran, kritikan dan ketidakpercayaan pembaca terhadap informasi yang diunggah. Diantaranya komentar dari pemilik akun@aliimran5222 menuliskan "kalo buruh kasar seperti saya, mau hujan/panas tetap aja bekerja”. Komentar ini mengandung makna sindiran bahwa informasi untuk tetap menjaga kesehatan pada saat musim penghujan yang diberikan oleh @kemenkes_ri berbanding terbalik dengan fenomena yang ada di lapangan untuk terus bekerja tanpa mengenal musim, demi memenuhi kebutuhan hidup. Komentar ini juga didukung oleh unggahan pemilik akun@ilunanam bahwa "ada yang dimakan saja sudah alhamdulliah, pak menteri kesehatan". Komentar yang muncul berupa kritikan bahwa kondisi ekonomi masyarakat saat ini sangat sulit, sehingga untuk makan ala kadarnya tanpa harus memperhatikan masakan itu bergizi atau tidak sudah sangat bersyukur, apalagi makanan yang bergizi menurut himbauan yang diberikan. Disamping itu muncul komentar dari pemilik akun@ade_lukmanto menuliskan "penyakitnya apa kok selalu ditunggangi si corona” kalimat tersebut merupakan kalimat interogatif yang mengandung makna rasa kurang percaya terhadap adanya virus corona yang selalu dijadikan alasan sebagai penyebab ketika seseorang sakit saat ini. Komentar yang 
muncul merupakan daya pengaruh dari apa yang dituturkan ataupun diunggah oleh seseorang. Ini dapat dibuktikan oleh hasil penelitian yang mengaji tentang tindak perlokusi melalui media video YouTube CNN Indonesia atas berita tentang Konpers Presiden soal Covid-19. Dalam penelitia tersebut didapati hasil yang menunjukkan efek beraneka ragam di antaranya efek tidak panik, efek takut, efek melakukan permintaan, efek melakukan kebijakan, efek melaksanakan perintah, efek senang, efek menerima ajakan, dan efek menuruti permintaan (Fatihah \& Utomo, 2020). Berbeda dengan hasil temuan dari Oktavia, bahwa dari 30 data tindak perlokusi hanya 10 data yang dapat merelevansi terbentuknya pendidikan karakter seseorang melalui album lagu Iwan Fals (Oktavia, 2019). Berdasarkan berbagai hasil penelitian telah membuktikan bahwa tindak perlokusi mampu memberikan daya pengaruh kuat terhadap mitra tutur.

\section{Data (3):}

\section{Konteks Situasi:}

Unggahan@kemenkes_ri mengandung himbauan untuk mengajak masyarakat tetap menerapkan 3M untuk mencegah penularan Covid-19. Terlihat dialog laki-laki dan perempuan dengan posisi duduk agak jauh sebagai bentuk penerapan 3M, yaitu menjaga jarak dan menggunakan masker. Tema yang dibahas dalam dialog adalah akan datang vaksin yang mampu mengubah pola hidup menjadi kembali normal.

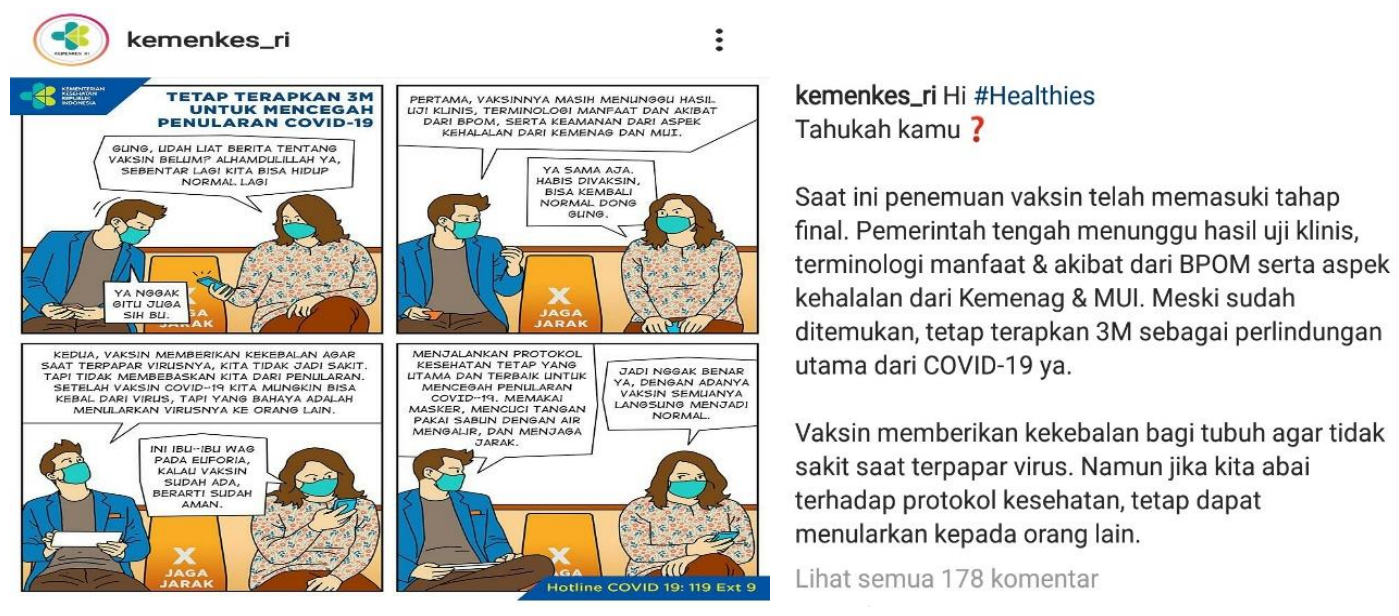

Gambar 5. Unggahan @kemenkes_ri tentang tetap terapkan 3M untuk mencegah penularan Covid-19
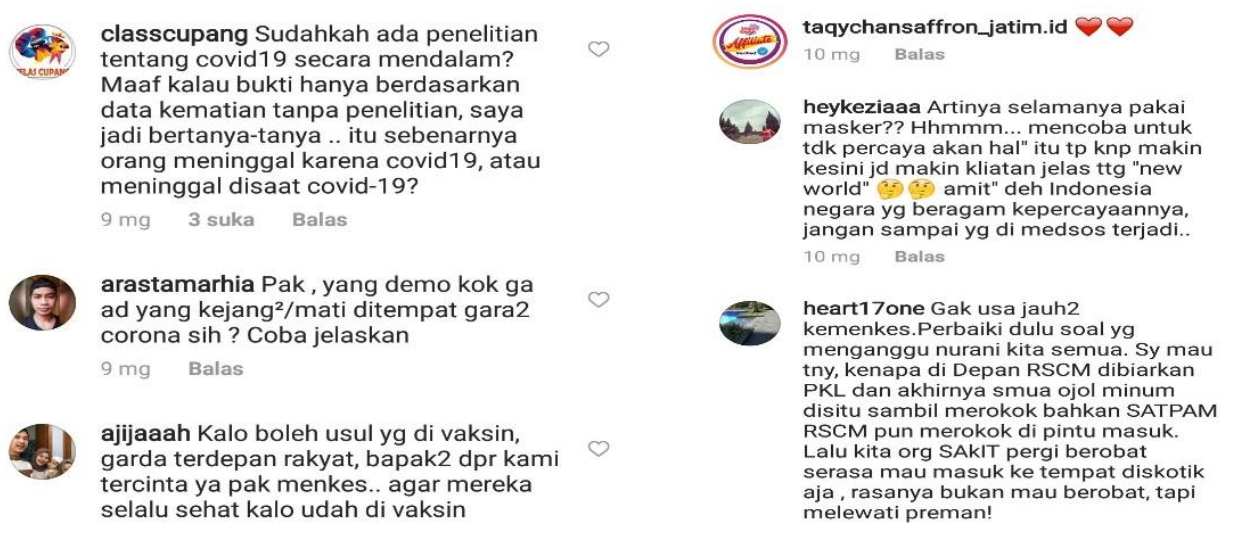

Gambar 6. Komentar pada unggahan @kemenkes_ri tentang tetap terapkan 3m untuk mencegah penularan Covid-19 


\section{Analisis Data (3):}

Data (3) merupakan hasil unggahan milik@kemenkes_ri, mengambil topik tentang penerapan 3M. Isi unggahan adalah mengajak masyarakat untuk tetap terapkan 3M guna mencegah penularan Covid-19. Unggahan agar terlihat menarik dan mudah dipahami oleh pembaca, pemilik akun @ kemenkes_ri menambahkan gambar atau disebut dengan komik gambar. Hasil unggahan pada konteks ini menghasilkan 178 komentar. Artinya unggahan tersebut mampu mempengaruhi mitra tutur yaitu pembaca atau sering disebut dengan followers. Berdasarkan pandangan para pakar linguistik tindak perlokusi bertujuan untuk memengaruhi mitra tutur selaku pihak kedua karena memiliki daya pengaruh (perlocutionary force) bagi mitra tutur (Kumalasari et al., 2018; Parker, 1986; Searle, 1985). Respons yang muncul beranekaragam baik komentar yang bersifat positif maupun negatif. Namun pada konteks ini komentar negatif jauh lebih bayak dibandingkan komentar positif.

Pemilik akun@Classcupang,yang menuliskan komentar menggunakan kalimat interogatif "Sudahkah ada penelitian tentang Covid secara mendalam, maaf kalo bukti hanya berdasarkan data kematian tanpa penelitian, saya jadi bertanya orang meninggal karena Covid atau saat Covid". Meskipun komentar yang ditulis oleh pembaca dalam bentuk kalimat interogatif namun mengandung makna menyindir kondisi saat ini. Selain itu, komentar pemilik akun@arastamarhia, juga menggunakan kalimat interogatif menanyakan para pendemo saat melakukan aksi belum terlihat yang kejang-kejang atau akibat terkena virus Corona. Melalui respons ini meminta penjelasan dari@kemenkes_ri agar mendapatkan pemahaman yang lebih pasti terkait adanya virus Corona yang sedang melanda Indonesia. Komentar yang muncul selain mengandung sindirian, juga bermakna saran sesuai komentar pemilik akun@HeartI7one, yang memberikan saran agar memperbaiki nurani masyarakat yang merasa takut karena adanya preman ketika akan masuk ke RSCM. Komentar mengandung saran juga ditulis oleh akun@ajijaaah, yang mengusulkan kepada bapak Menkes bahwa yang paling penting penerima vaksin dimulai dari rakyat dan bapak DPR. Berbeda dengan komentar dari akun@ @heykeziaaa, yang menuliskan komentar mengonfirmasi tentang penggunaan masker selamanya dan ketidaksetujuan adanya new word akibat dampak pandemi. Pada konteks ini juga ditemukan adanya komentar positif dari akun @ taqychansaffron-jatim.id, yang mengunggah simbol jantung sebagai bentuk dukungan positif terhadap informasi yang diberikan oleh @kemenkes_ri yang sangat bermanfaat bagi pembaca. Komentar yang muncul sebagai bentuk daya pengaruh dari hasil unggahan tidak saja mengandung makna positif maupun negatif, namun ada juga mengandung makna saran seperti beberapa komentar yang telah disampaikan pada data di atas. Kondisi ini sejalan dengan pandangan (Rahardi, 2020) bahwa tindak perlokusi dapat menumbuhkan berbagai persepsi, tergantung dari pola pikir pembaca saat menyikapi hasil postingan di media sosial instagram. Selain itu, kuatnya daya pengaruh hasil unggahan sebagai bentuk dari perwujudan tindak tutur perlokusi (Tsoumou, 2020). 
Data (4):

\title{
Konteks Situasi:
}

Unggahan pada konteks ini menceritakan tentang adaptasi kebiasaan baru di pasar tradisional dalam bentuk dialog para ibu-ibu ketika berada di pasar tradisional. Isi unggahan memberikan himbauan kepada masyarakat yang ingin berbelanja ke pasar tradisional dan diharapkan untuk mentaati protokol kesehatan.
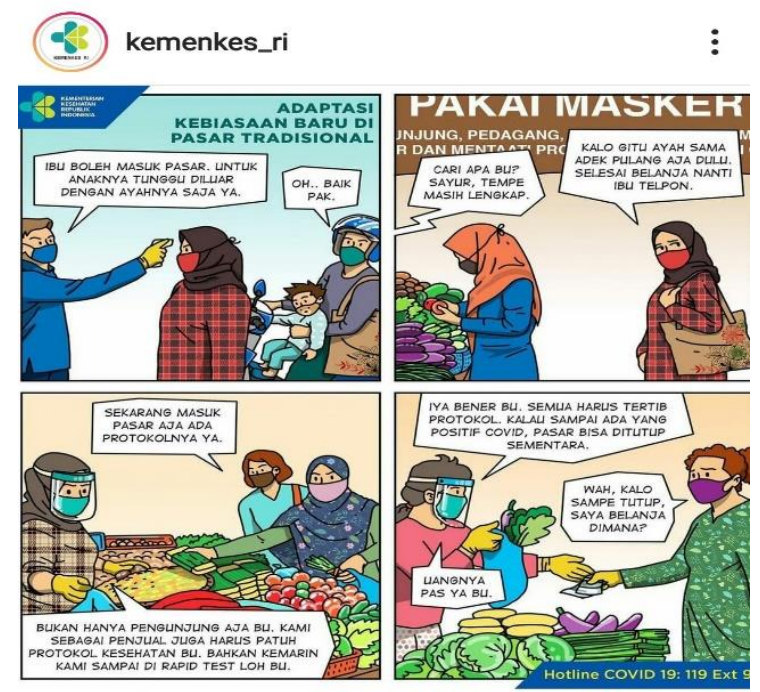

\author{
kemenkes_ri Selamat Pagi \#\#healthies
}

Bagi \#Healthies yang ingin berbelanja di pasar tradisional, sudah tahu belum apa saja yang menjadi protokol kesehatan saat kita berada di pasar tradisional? Saat masa Adaptasi Kebiasaan Baru ini kita harus tetap disiplin menjalankan protokol kesehatan ya jangan abai dengan kesehatan. Yuk simak komik sehat berikut

Lihat semua 550 komentar

Gambar 7.Unggahan @kemenkes_ri tentang adaptasi kebiasaan baru di pasar tradisional
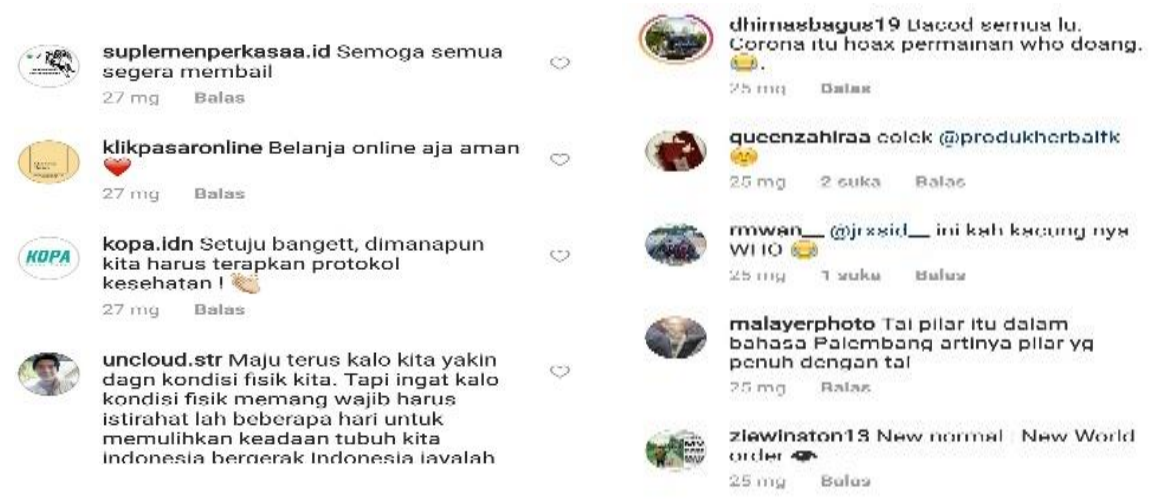

Gambar 8. Komentar pada unggahan @kemenkes_ri tentang adaptasi kebiasaan baru di pasar tradisional

Pada data (4) terlihat secara jelas komik gambar dalam bentuk dialog tertulis diikuti oleh gambar. Unggahan berupa teks ditulis menggunakan kalimat interogatif, seolah-olah mengajukan pertanyaan kepada pembaca tentang protokol kesehatan ketika berada di pasar tradisional. Kemudian dilanjutkan dengan pemaparan singkat himbauan kepada masyarakat yang ingin berbelanja ke pasar tradisional serta harapan untuk mentaati protokol kesehatan. Terlihat secara jelas hasil unggahan pengguna instagram akun@kemenkes_ri yang bertemakan tentang himbauan kepada masyarakat saat berbelanja di pasar tradisional, karena didukung oleh gambar yang menarik untuk dibaca. Unggahan ini sangat menarik dan mudah dipahami oleh pembaca, sehingga memunculkan 550 komentar yang terposting. Komentar yang muncul baik positif maupun negatif namun dalam konteks ini lebih banyak komentar negatif. Hal ini dapat dilihat pada teks yang ditulis oleh pembaca pemilik akun@dhimasbagus19, yang menuliskan "Bacod semua lu. Corona itu hoax permainan WHO doang" dan beberapa pemilik akun lain mengungkapkan dalam bentuk teks makna kekecewaan dan rasa kurang percaya adanya virus Covid-I9. Makna yang terkandung dari hasil unggahan mencerminkan rasa tidak 
percaya penulis terhadap adanya virus Corona. Begitu besar daya pengaruh dari unggahan ini, sehingga mampu memancing komentar pembaca untuk meluapkan suasana hati mereka. Berbeda dengan komentar mengandung respons positif umumnya mereka menuliskan kata-kata bijak yang bermakna mendukung dan harapan positif agar kondisi kembali normal. Berbagai komentar yang bernada positif maupun negatif merupakan daya tindak tutur perlokusi. Hal ini sejalan dengan pandangan dari para peneliti sebelumnya (Mujianto, 2015; Mukhroji et al., 2019; Pande \& Artana, 2020; Rahardi, 2020) bahwa meskipun dalam berbagai ranah kajian penelitian, namun tindak tutur perlokusi mampu menumbuhkan suatu daya pengaruh terhadap pembaca selaku pengguna akun lain. Hal ini dibuktikan dengan munculnya berbagai komentar baik positif maupun negatif dari hasil unggahan pemilik akun instagram@kemenkes_ri dalam memberikan berbagai informasi terkini tentang Covid-19.

\section{SIMPULAN}

Daya tindak perlokusi terbentuk tidak saja dari unggahan secara lisan, melainkan secara teks juga mampu menghasilkan suatu daya pragmatik dari pembacanya. Unggahan bertema Covid-I9 dari pemilik akun @kemenkes-ri mampu menumbuhkan daya tindak perlokusi. Hal ini dapat dilihat dari banyak munculnya komentar dari pembaca media sosial instagram. Baik komentar positif maupun negatif. Respons positif bentuk apresiasi, dukungan serta harapan terhadap kebijakan dan kegiatan pemerintah, sedangkan respons negatif mengandung kekecewaan, kemarahan, kekesalan, pertanyaan rasa kurang percaya terhadap kebijakan pemerintah dalam menangani Covid-I9. Berbagai respons masyarakat ini dapat mewakili aspirasi rakyat kepada pemerintah agar dapat lebih baik lagi memberikan kesejahteraan dan kenyamanan kepada masyarakat dalam menangani kasus Covid-19. Berdasarkan fenomena ini memberikan suatu pembelajaran bagi para pemilik akun di instagram, khususnya milik pemerintah, yang berperan sebagai media informasi yang mudah dilihat dan dipahami oleh masyarakat selaku pembaca. Hal ini dimaksudkan agar unggahan topik berfungsi untuk memberikan informasi yang jelas, tidak bertele-tele, dan apa adanya sesuai dengan fenomena sebenarnya. Tidak menutup kemungkinan bahwa daya perlokusi juga dapat muncul di berbagai tema, tidak hanya membahas seputar Covid-19. Kontribusi dari penelitian ini dapat dilihat dari berbagai respons pengguna dapat mewakili aspirasi rakyat kepada pemerintah untuk lebih sigap dalam menangani kasus Covid-I9 di Indonesia.

\section{DAFTAR PUSTAKA}

Andriyani, A. A. A. D. (2020). Phenomenon of multilingual society among tourist actors: A case study at Kuta Beach of Bali. E-Review of Tourism Research, I776), 82I-836. Retrieved from https://ertr-ojs-tamu.tdl.org/ertr/index.php/ertr/article/view/279

Andriyani, A. A. A. D., Djatmika, D., Sumarlam, S., \& Rahayu, E. T. (2019). Pengaruh lintas budaya tingkat tutur hormat keigo melalui media sosial antara driver guide dan wisatawan Jepang di Bali. MOZAIK HUMANIORA, I9(I), I-I7. https://dx.doi.org/I0.20473/mozaik.vI9iI.II976

Austin, J. L. (1962). How to do things with words. Inggris: Oxford University.

Bou-Franch, P., \& Garcés-Conejos Blitvich, P. (20I4). The pragmatics of textual participation in the social media. Journal of Pragmatics, $73, \quad$ I-3. https://doi.org/https://doi.org/I0.1016/j.pragma.2014.08.009

Citrawati, N. P. E. W., Teguh, I. W., \& Widarsini, N. P. N. (2020). Pragmatic functions of Indonesian in the column "smart traveler" of the Bali tribun newspaper. Journal of Applied Studies in Language, 4(2), 273-280. http://dx.doi.org/I0.31940/jas1.v4i2.2II0

Fatihah, A. C., \& Utomo, A. P. Y. (2020). Analisis tindak tutur perlokusi dalam konpers presiden soal Covid-19 pada saluran youtube CNN Indonesia. Metamorfosis/ Jurnal Bahasa, Sastra Indonesia dan Pengajarannya, I3(I), I-I0. Retrieved from http://ejournal.unibba.ac.id/index.php/metamorfosis/article/view/298

Fatma, K. S. (2016). The Form and function of local language in directive speech act at a university in Central Sulawesi. Lingua Cultura, IO(I), 37-42. https://doi.org/I0.215I2/1c.vI0iI.848 
Hamidah, J., \& Normuliati, S. (2015). Analisis tindak tutur endorse di media sosial instagram. Banjarmasin: Universitas Muhammadiyah Banjarmasin.

Hartati, M. (2016). Kajian tindak tutur wacana "buat akta usia dewasa" koran Tribun Pontianak. Jurnal Pendidikan Bahasa, 4(2), 243-252. http://dx.doi.org/I0.3157I/bahasa.v4i2.93

Jumanto, J., Nugroho, R. A., \& Basari, A. (2018). Pragmatics and translation: a preliminary study. In disclaimer: The editors of the proceedings of The I2th Malaysia International Conference on English Language Teaching (MICELT) 20I8-Shaping New Understandings in ELT hereby state that the papers (p. I7).

Kempson, R. M. (1977). Semantic theory. Cambridge: University Press.

Khalisah, A., \& Anjarningsih, H. Y. (2020). "Taking it for granted": The utilization of pragmatic aspects in entertainment news reporting on instagram. Indonesian Journal of Applied Linguistics, (3), 508-516. https://doi.org/I0.17509/ijal.v9i3.23200

Kumalasari, M. A., Rustono, R., \& Santoso, B. W. J. (2018). Strategi kesantunan pemandu acara talkshow Kick Andy dan Mata Najwa di Metro TV. JP-BSI (Jurnal Pendidikan Bahasa dan Sastra Indonesia), 3(I), 34-43. http://dx.doi.org/I0.26737/jp-bsi.v3iI.446

Lee, H., Lee, B., \& Chun, H. C. (2018). Refusal speech act response: Differences between South Koreans and north Korean refugees in inducing speech acts and directness. GEMA Online Journal of Language Studies, I8(2), I7-30. https:/ / doi.org/I0.I7576/gema-2018-I802-02

Leech, G. (1996). Principles of Pragmatics. New York: Longman.

Meylinda, H. (2019). Tindak tutur host Aiman Terhadap narasumber dalam wawancara langsung di program Aiman Kompas TV. Bapala, 5(2), I-I4. Retrieved from https://jurnalmahasiswa.unesa.ac.id/index.php/bapala/article/view/29008/26558

Mujianto, G. (2015). Tindak tutur guru dalam pembelajaran menulis dengan komposisi terarah berdasarkan tingkat kognisi siswa. KEMBARA: Jurnal Keilmuan Bahasa, Sastra, dan Pengajarannya (e-journal), I(2), I73-I97. https://doi.org/I0.22219/kembara.vIi2.26I4

Mukhroji, M., Nurkamto, J., Subroto, H. D. E., \& Tarjana, S. S. (2019). Pragmatic forces in the speech acts of EFL speakers at kampung Inggris, Indonesia. Journal of Social Studies Education Research, IO(I), 38-60. Retrieved from https://dergipark.org.tr/en/pub/jsser/issue/45447/570402

Netra, I. M. (2013). Daya ilokusi ngidih 'permintaan'perspektif wacana kebudayaan bali. Linguistika $\begin{array}{llll}\text { Kultura, } & 6(3) . & \text { Retrieved } & \text { from }\end{array}$ http://jurnalvivid.fib.unand.ac.id/index.php/lingkul/article/view/42/5I

Nuramila. (2017). Analisis tindak tutur bahasa Indonesia dalam unggahan media sosial instagram@ sastgascovidI9.id (kajian pragmatik). In Seminar Internasional Riksa Bahasa(pp. 74-79). Universitas Negeri Makasar, 6(c).

Oktavia, W. (2019). Metaphor and interpretation of social criticism of community in Iwan Fals albums. Jurnal Kata: Penelitian Tentang Ilmu Bahasa dan Sastra, 3(I), I5-22. http://doi.org/I0.222I6/kata.v3iI.3882

Pande, N. K. N. N., \& Artana, N. (2020). Kajian pragmatik mengenai tindak tutur bahasa indonesia dalam unggahan media sosial instagram@ halostiki. Alfabeta: Jurnal Bahasa, Sastra, dan Pembelajarannya, 3(I), 32-38. https://doi.org/I0.33503/alfabeta.v3iI.766

Parker. (1986). Language and Pragmatic. Harmoundswort: Penguin Education.

Pramujiono, A., Suhari, S., Indrayanti, T., \& Rochmawati, D. (2019). Recounting as realization of Brown and Levinson'S positive politeness strategies in instructional interactions. KEMBARA: Jurnal Keilmuan Bahasa, Sastra, dan Pengajarannya (e-journal), 5(2), 137. https://doi.org/I0.22219/kembara.vo15.no2.137-I45

Rahardi, R. K. (2020). Perlokusi hoaks Covid-I9: Perspektif cyberpragmatics. LITERA, I9(3), 47I486. Retrieved from https://repository.usd.ac.id/38450/I/653I_3I469-96893-I-PB-litera.pdf 
Rahayu, S. (2020). Types of speech acts and principles of mother's politeness in mother and child conversation. KEMBARA: Jurnal Keilmuan Bahasa, Sastra, dan Pengajarannya (e-journal), 6(I), I-9. doi: https://doi.org/I0.22219/kembara.v6iI.II695

Safar, M. (2016). Tindak tutur direktif dalam transaksi jual beli di pasar sentral Watampone. Humanus, $\quad X V(2), \quad$ I67-I76. $\quad$ Retrieved from https:// ejournal.unp.ac.id/index.php/humanus/index

Safrihady, S., \& Mardikantoro, H. B. (2017). Jenis dan fungsi pragmatis tindak tutur masyarakat Melayu dialek Sambas di Kota Singkawang. Seloka: Jurnal Pendidikan Bahasa dan Sastra $\begin{array}{llll}\text { Indonesia, } & 6(\mathrm{I}), & 3 \mathrm{I} 2 . & \text { Retrieved }\end{array}$ https://journal.unnes.ac.id/sju/index.php/seloka/article/view/I4766

Searle, J. R. (1985). Expression and meaning: Studies in the theory of speech acts. Cambridge: Cambridge University Press.

Shaari, A. H. (2020). Accentuating illocutionary forces: Emoticons as speech act realization strategies in a multicultural online communication environment. 3L: Language, Linguistics, Literature, 26(I), I35-I55. https:// doi.org/I0.I7576/3L-2020-260I-I0

Sudaryanto. (2015). Metode dan teknik analisis bahasa. Yogyakarta: Sanata Dharma University Press.

Suryani, I. (20I4). Pemanfaatan media sosial sebagai media pemasaran produk dan potensi Indonesia dalam upaya mendukung ASEAN community 20I5. (Studi Social Media Marketing Pada Twitter Kemenparekraf RI dan Facebook Disparbud Provinsi Jawa Barat). Jurnal Komunikasi, 8(2), I23-I38. https:// doi.org/I907-898X

Susanti, R., Siregar, M., Bahasa, J., Sastra, F., Nasional, U., Manila, J. S., \& Minggu, P. (2010). Tindak tutur memuji bahasa Jepang di kalangan wanita Jepang. Lingua Cultura, 4(I), 78 89. https://doi.org/I0.2I5I2/1c.v4iI.354

Tsoumou, J. M. (2020). Analysing speech acts in politically related facebook communication. Journal of Pragmatics, I67, 80-97. https://doi.org/https://doi.org/I0.I016/j.pragma.2020.06.004

Wulan, A. P. (2016). Analisis tindak tutur dalam iklan motor dan mobil dalam harian umum Solopos (edisi 2I Juni 20II). Jurnal Pendidikan Bahasa, 2(2), I49_ I64. http:/ / dx.doi.org/I0.3 I57I/bahasa.v2i2.240

Yule, G. (1996). Pragmatics. Oxford: Oxford University Press. 